\title{
A Lyophilized Water Extract of Melissa officinalis L. as an Effective Natural Antioxidant during the Storage of Dry Fermented Sausages High in $\alpha$-Linolenic Acid and DHA
}

Mikel García-Íñiguez de Ciriano, Eduardo Larequi, Izaskun Berasategi, María Isabel Calvo, Rita Yolanda Cavero, Íñigo Navarro-Blasco, Iciar Astiasarán and Diana Ansorena

Faculty of Pharmacy, University of Navarra, C/Irunlarrea s/n, Pamplona 31008, Spain

Received: October 26, 2011 / Published: January 20, 2012.

\begin{abstract}
A pre-emulsified mixture of linseed and algae oils (15/10) and stabilized with $686 \mathrm{ppm}$ of a lyophilized water extract of Melissa officinalis, was successfully applied in dry fermented sausages to increase the $\omega-3$ PUFA content. The objective of this work was to evaluate the stability of this modified formulation during the storage and to compare it to that of a traditional formulation. Traditional and modified products were stored during 90 days at $4{ }^{\circ} \mathrm{C}$ in aerobic conditions. Fatty acid profiles, TBARS and volatile compounds derived from oxidation were analyzed at 0,30 and 90 days of storage. The fatty acid profiles did not significantly change along the storage period. The stabilizing effect of the natural antioxidants of $M$. officinalis could contribute to detect no losses of $\omega$ - 3 PUFA in Modified (30 days: $2.13 \mathrm{~g} / 100 \mathrm{~g}$ of product, 90 days: $2.33 \mathrm{~g} / 100 \mathrm{~g}$ of product), whereas in Control products a slightly significant reduction was detected ( 30 days: $0.34 \mathrm{~g} / 100 \mathrm{~g}$ of product, 90 days: $0.29 \mathrm{~g} / 100 \mathrm{~g}$ of product). After 90 days, the increases of TBARS and hexanal content were much higher in Control than in Modified (Control: $1.41 \mathrm{mg}$ MDA/kg \& 17,915 ng dodecane/kg of dry matter; Modified: $0.48 \mathrm{mg}$ MDA $/ \mathrm{kg} \& 2,496 \mathrm{ng}$ dodecane $/ \mathrm{kg}$ of dry matter). In conclusion, the lyophilized water extract of $M$. officinalis protected high $\omega-3$ PUFA of dry fermented sausages from oxidation along the storage time, guaranteeing the nutritional improvements achieved with the modified formulation.
\end{abstract}

Key words: Natural antioxidants, oxidation, sausages, omega-3, linseed oil, algae oil.

\section{Introduction}

Recently many authors have developed strategies to obtain new formulations of healthier meat products trying to improve their lipid fraction [1-10]. The lipid profile modification implies an increase of the poly-unsaturated (PUFA) fraction, specially of the $\omega-3$ PUFA content, leading to a lower $\omega-6 / \omega-3$ ratio, in order to achieve the current recommendations [11], and consequently, obtaining some beneficial effects as protective role against cardiovascular risk factors, inflammatory effects, sudden death, obesity,

Corresponding author: Diana Ansorena, professor, research field: food science. E-mail: dansorena@unav.es. insulin-resistance and mental illness [12-18]. However, a described drawback for this strategy points out that the inclusion of a higher PUFA content involves a higher lipid oxidation susceptibility, developing off-flavour volatile compounds deteriorating the quality, color and even the nutritional value of the products $[19,20]$. Consequently, the acceptability of the meat and meat products could be compromised [21].

With the aim of preventing the oxidation of meat products, compounds with antioxidant activity should be included in the formulation, being an effective mean for delaying lipid oxidation [22]. Ansorena [2] 
used BHA + BHT as inhibitors of the lipid oxidation in dry fermented sausages enriched in $\omega-3$ PUFA. In the last years, the use of natural sources of antioxidants against the development of rancidity in food and also, in the protection on the human health, are being studied as an interesting approach in food research [23-25]. Food industry has shown great interest on vegetable extracts from medicinal plants, spices, fruits and edible plants due to their technological and healthy roles. These products, in some cases, had shown a greater antioxidant efficacy than synthetic antioxidants, which is attributed to their content in antioxidant compounds such as polyphenols, lycopene and $\alpha$-Tocopherol [8, 26-30]. In particular, Melissa officinalis (Lemon balm) is an edible plant that belongs to the Lamiaceae family, and it is considered an interesting source of antioxidant components [31]. In fact, the antioxidant properties of methanolic and ethanolic extracts of Melissa officinalis have been already pointed out [32].

The objective of this work was to evaluate the stability during storage of dry fermented sausages enriched in $\omega-3$ PUFA by means of a pre-emulsified mixture of linseed and algae oils and stabilized by a lyophilized water extract of Melissa officinalis L.

\section{Material and Methods}

\subsection{Experimental Design}

Water extracts of Melissa officinalis were prepared as follows: $50 \mathrm{~g}$ of dried leaves were weighted and added to $500 \mathrm{~mL}$ of distilled water, preheated at $100{ }^{\circ} \mathrm{C}$. The mixture was subjected to reflux during 30 minutes at the temperature above. Extraction process was repeated with another $500 \mathrm{~mL}$ of distilled water, and both extracts were joined and completed with distilled water to a final volume of $1 \mathrm{~L}$. Extracts were filtered using filter to remove insoluble particles. Water extraction was performed in triplicate.

The extracts were lyophilized with a freeze-dryer-cryodo (Telstar, Barcelona, Spain), previous freezing at $-80{ }^{\circ} \mathrm{C}$ in a MDF-V5386S
Ultra-Low-Temperature Freezer (Sanyo Electric Co., Ltd., Japan). $21.8 \mathrm{~g}$ of lyophilized material were obtained from $100 \mathrm{~g}$ of Melissa dried leaves. The lyophilized material was subsequently used for the evaluation of the antioxidant capacity and for application as ingredient in the dry fermented sausage formulation.

$686 \mathrm{ppm}$ of this lyophilized water extract of Melissa officinalis L. were used for controlling the lipid oxidation of a pre-emulsified mixture of linseed and algae oils (15/10). According to the procedure described by García-Íñiguez de Ciriano [9] this emulsion was used as a partial substitute of $25 \%$ of the pork back fat in a particular type of dry fermented sausages (Chorizo) (Modified). A batch prepared according to a traditional formulation was used as Control (Control). Processing conditions are those described by Muguerza [33].

Control and Modified products were stored during 90 days at $4{ }^{\circ} \mathrm{C}$ in aerobic conditions. Total fatty acid profiles, TBARS and volatile compounds derived from oxidation were analyzed at 0 (Final product), 30 and 90 days of storage.

\subsection{Determination of the Total Fatty Acid Profile}

The method of Folch [34] was used for the extraction of lipids. Fatty acids were determined in the lipid extract by gas chromatography, previous methylation with boron trifluoride/methanol [35]. The quantification of fatty acids was based on the internal standard method, using heptadecanoic acid methyl ester (Sigma, St. Louis, MO, USA).

\subsection{Determination of TBARS Value}

TBARS value was determined according to Tarladgis [36] with modifications by Tarladgis [37]. Results are shown in mg malonaldehyde (MDA)/kg sample.

\subsection{Volatile Compounds from Lipid Oxidation}

A Likens-Nickerson extraction followed by a 

the storage of dry fermented sausages high in a-linolenic acid and DHA

GC-MS detection and quantification was carried out according to the method described by Ansorena [38]. The results were expressed as nanograms of dodecane (Internal Standard) per gram of dry matter.

\subsection{Statistical Analysis}

The experimental data were submitted to an ANOVA analysis at a 5\% level of significance, testing the differences among the different storage times with the Tuckey $b$ post hoc test. The differences between batches were analyzed by a Student $t$ test being the signification $P<0.05\left(^{*}\right), P<0.01(* *)$, or $P<0.001$ $(* * *)$ (SPSS 15.0).

\section{Results and Discussion}

The enrichment of dry fermented sausages with linseed and algae oils increased the content on $\alpha$-linolenic acid (ALA) and docosahexaenoic acid
(DHA) in the products [9]. The changes in the lipid profile of these products were analyzed during their storage period (Table 1). After 30 days of storage, no significant differences were found for ALA compared to Final product in Modified batches, whereas a slight reduction was noticed after 90 days $(1.6 \%)$. Valencia [39] did not find significant differences of ALA in dry fermented sausages enriched in linseed oil and stabilized with synthetic antioxidants (BHA + BHT) when they were stored from 2 to 5 months in aerobic condition. Besides, in the present work, DHA remained constant in the Modified batches $(1.99 \pm$ $0.01 \mathrm{~g} / 100 \mathrm{~g}$ of FAME) along the storage. Also, the total $\omega-6$ content was not modified during the storage. In consequence, the interesting $\omega-6 / \omega-3$ ratio observed in the final product (1.96) was kept below 2 until the end of storage, and was significantly lower than that observed for Control products (mean $=16$ ). The different

Table 1 Fatty acids, fatty acid fractions and important ratios obtained for control and modified dry fermented sausages along their aerobic storage at $4^{\circ} \mathrm{C}$ (results are expressed in $\mathrm{g} / 100 \mathrm{~g}$ of FAME as mean \pm standard deviation).

\begin{tabular}{|c|c|c|c|c|c|c|c|}
\hline & & Final product & $\mathrm{LS}$ & 30 days & LS & 90 days & LS \\
\hline \multirow{2}{*}{$\begin{array}{l}\alpha \text {-Linolenic } \\
\text { C18:3( } \omega-3)\end{array}$} & Control & $0.92 \pm 0.01^{\mathrm{b}}$ & \multirow{2}{*}{$* * *$} & $0.94 \pm 0.02^{\mathrm{c}}$ & \multirow{2}{*}{$* * *$} & $0.85 \pm 0.01^{\mathrm{a}}$ & \multirow{2}{*}{$* * *$} \\
\hline & Modified & $4.82 \pm 0.01^{\mathrm{b}}$ & & $4.75 \pm 0.08^{\mathrm{a}, \mathrm{b}}$ & & $4.67 \pm 0.01^{\mathrm{a}}$ & \\
\hline \multirow{2}{*}{ 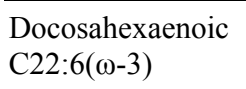 } & Control & $0.05 \pm 0.00^{\mathrm{b}}$ & \multirow{2}{*}{$* * *$} & $0.06 \pm 0.00^{\mathrm{a}}$ & \multirow{2}{*}{$* * *$} & $0.05 \pm 0.00^{\mathrm{b}}$ & \multirow{2}{*}{$* * *$} \\
\hline & Modified & $2.00 \pm 0.07^{\mathrm{a}}$ & & $1.98 \pm 0.08^{\mathrm{a}}$ & & $1.98 \pm 0.02^{\mathrm{a}}$ & \\
\hline \multirow{2}{*}{ SFA } & Control & $36.75 \pm 0.18^{b}$ & \multirow{2}{*}{$* * *$} & $36.50 \pm 0.02^{\mathrm{a}}$ & \multirow{2}{*}{$* * *$} & $36.92 \pm 0.03^{\mathrm{b}}$ & \multirow{2}{*}{$* * *$} \\
\hline & Modified & $35.05 \pm 0.04^{\mathrm{b}}$ & & $34.94 \pm 0.09^{\mathrm{a}}$ & & $34.88 \pm 0.02^{\mathrm{a}}$ & \\
\hline \multirow{2}{*}{ MUFA } & Control & $45.41 \pm 0.25^{\mathrm{a}, \mathrm{b}}$ & \multirow{2}{*}{ ns } & $45.25 \pm 0.31^{\mathrm{a}}$ & \multirow{2}{*}{$* *$} & $45.80 \pm 0.05^{\mathrm{b}}$ & \multirow{2}{*}{$* * *$} \\
\hline & Modified & $43.68 \pm 0.07^{\mathrm{a}}$ & & $43.95 \pm 0.06^{\mathrm{b}}$ & & $44.05 \pm 0.02^{\mathrm{b}}$ & \\
\hline \multirow{2}{*}{ PUFA } & Control & $16.74 \pm 0.06^{\mathrm{b}}$ & \multirow{2}{*}{$* * *$} & $17.16 \pm 0.27^{\mathrm{c}}$ & \multirow{2}{*}{$* * *$} & $16.21 \pm 0.02^{\mathrm{a}}$ & \multirow{2}{*}{$* * *$} \\
\hline & Modified & $20.29 \pm 0.04^{b}$ & & $20.14 \pm 0.14^{\mathrm{a}, \mathrm{b}}$ & & $20.10 \pm 0.03^{\mathrm{a}}$ & \\
\hline \multirow{2}{*}{$\omega-3$} & Control & $1.00 \pm 0.01^{\mathrm{b}}$ & \multirow{2}{*}{$* * *$} & $1.04 \pm 0.02^{\mathrm{c}}$ & \multirow{2}{*}{$* * *$} & $0.92 \pm 0.01^{\mathrm{a}}$ & \multirow{2}{*}{$* * *$} \\
\hline & Modified & $6.86 \pm 0.07^{\mathrm{b}}$ & & $6.78 \pm 0.08^{\mathrm{a}, \mathrm{b}}$ & & $6.71 \pm 0.02^{\mathrm{a}}$ & \\
\hline \multirow{2}{*}{$\omega-6$} & Control & $15.74 \pm 0.05^{\mathrm{b}}$ & \multirow{2}{*}{$* * *$} & $16.12 \pm 0.25^{\mathrm{c}}$ & \multirow{2}{*}{$* * *$} & $15.29 \pm 0.02^{\mathrm{a}}$ & \multirow{2}{*}{$* * *$} \\
\hline & Modified & $13.43 \pm 0.03^{\mathrm{a}}$ & & $13.36 \pm 0.09^{\mathrm{a}}$ & & $13.39 \pm 0.01^{\mathrm{a}}$ & \\
\hline \multirow{2}{*}{$\omega-6 / \omega-3$} & Control & $15.69 \pm 0.15^{\mathrm{a}}$ & \multirow{2}{*}{$* * *$} & $15.45 \pm 0.14^{\mathrm{a}}$ & \multirow{2}{*}{$* * *$} & $16.60 \pm 0.14^{b}$ & \multirow{2}{*}{$* * *$} \\
\hline & Modified & $1.96 \pm 0.02^{\mathrm{a}}$ & & $1.97 \pm 0.02^{\mathrm{a}, \mathrm{b}}$ & & $2.00 \pm 0.01^{\mathrm{b}}$ & \\
\hline \multirow{2}{*}{ PUFA/SFA } & Control & $0.46 \pm 0.00^{\mathrm{b}}$ & \multirow{2}{*}{$* * *$} & $0.47 \pm 0.01^{\mathrm{c}}$ & $* * *$ & $0.44 \pm 0.00^{\mathrm{a}}$ & $* * *$ \\
\hline & Modified & $0.58 \pm 0.00^{\mathrm{a}}$ & & $0.58 \pm 0.01^{\mathrm{a}}$ & ara & $0.58 \pm 0.00^{\mathrm{a}}$ & 等 \\
\hline PUFA+MUFA & Control & $1.69 \pm 0.01^{\mathrm{b}}$ & $* * *$ & $1.71 \pm 0.00^{\mathrm{b}}$ & $* * *$ & $1.68 \pm 0.00^{\mathrm{a}}$ & $* * *$ \\
\hline /SFA & Modified & $1.83 \pm 0.00^{\mathrm{a}}$ & W & $1.83 \pm 0.01^{\mathrm{b}}$ & $T_{n}$ & $1.84 \pm 0.00^{\mathrm{b}}$ & $x_{n}$ \\
\hline & Control & $0.99 \pm 0.02^{\mathrm{a}}$ & $* *$ & $0.98 \pm 0.02^{\mathrm{a}}$ & $* * *$ & $0.98 \pm 0.03^{\mathrm{a}}$ & $* * *$ \\
\hline trans & Modified & $0.85 \pm 0.04^{\mathrm{a}}$ & Fa & $0.83 \pm 0.01^{\mathrm{a}}$ & Fas & $0.84 \pm 0.01^{\mathrm{a}}$ & Na* \\
\hline
\end{tabular}

Student't test compares differences between both types of dry fermented sausages. LS (level of significance): ns (not significant); $P>$ $0.05 ; * P<0.05$; ** $P<0.01$; *** $P<0.001$. Different letters in the same row denote significant differences $(P<0.05)$ among the different times according to an ANOVA test and Tuckey $b$ post hoc test. 
A Lyophilized water extract of Melissa officinalis L. as an effective natural antioxidant during the storage of dry fermented sausages high in $\alpha$-linolenic acid and DHA

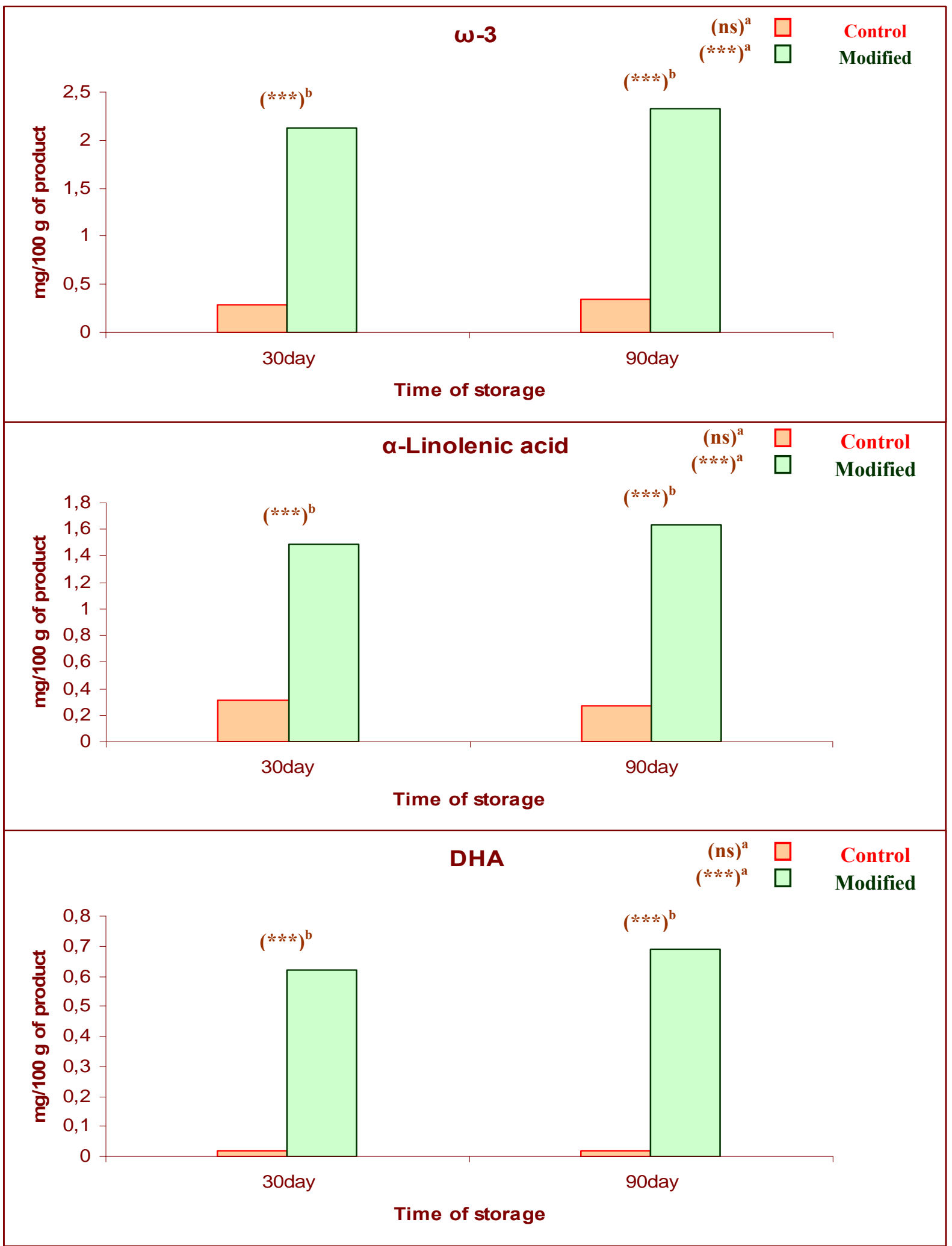

Fig. $1 \omega-3$, ALA and DHA content in dry fermented sausages ( $\mathrm{mg} / 100 \mathrm{~g}$ of product).

Two Student't tests compare differences between 30 day vs 90 day for Control and Modified batches respectively $\left({ }^{\mathrm{a}}\right)$ and Control vs Modified for 30 days and 90 days, respectively $\left({ }^{b}\right)$. Level of significance: ns (not significant); $P>0.05 ; * P<0.05 ; * * P<0.01 ; * * *$ $P<0.001$. 
natural susceptibility of SFA (saturated fatty acids) and PUFA to oxidation might induce changes of the ratio PUFA/SFA along storage. However, this ratio remained constant as well, pointing to the high stability of the new formulation.

Results expressed on basis on $100 \mathrm{~g}$ product confirmed again the stability of the PUFA fraction in Modified products (Fig. 1). Even slight increases of $\omega-3$, ALA and DHA were detected after 90 days compared to 30 days of storage, which could be attributed both to the maintenance of the fatty acids un-oxidized and to a slight loss of moisture during the aerobic conditions of storage.

In summary, the nutritional improvement of the new formulation reported by García-Íñiguez de Ciriano [9] could be guaranteed along the self-life of the products, due to the adequate preservation of these compounds by the protective role of $M$. officinalis.

Although the modified formulation resulted in a healthier product along the time, it is greatly important to evaluate the stability problems related to the potential lipid oxidation that might overcome along the storage time. Results obtained from TBARS analysis did not show relevant oxidation problems in the tested experimental conditions (Table 2). During the first 30 days, Modified batches showed higher values than Control batches. After 90 days of storage, the TBARS was only $0.48 \mathrm{ppm}$ in Modified batches

Table 2 Parameters related with the lipid oxidation in the dry fermented sausages.

\begin{tabular}{|c|c|c|c|c|c|c|c|}
\hline & & Final product & LS & 30 days & LS & 90 days & $\mathrm{LS}$ \\
\hline \multirow{2}{*}{ TBARS } & Control & $0.09 \pm 0.01^{\mathrm{a}}$ & \multirow{2}{*}{$* *$} & $0.10 \pm 0.01^{\mathrm{a}}$ & \multirow{2}{*}{$* * *$} & $1.41 \pm 0.10^{\mathrm{b}}$ & \multirow{2}{*}{$*$} \\
\hline & Modified & $0.11 \pm 0.01^{\mathrm{a}}$ & & $0.25 \pm 0.01^{\mathrm{b}}$ & & $0.48 \pm 0.01^{\mathrm{c}}$ & \\
\hline \multirow{2}{*}{ Hexanal } & Control & $1,369.51 \pm 122.31^{\mathrm{a}}$ & \multirow{2}{*}{$*$} & $1,924.72 \pm 744.11^{\mathrm{a}}$ & \multirow{2}{*}{ ns } & $17,915.40 \pm 569.87^{b}$ & \multirow{2}{*}{$* * *$} \\
\hline & Modified & $813.55 \pm 365.75^{\mathrm{a}}$ & & $1,476.20 \pm 396.13^{\mathrm{a}}$ & & $2,496.07 \pm 435.96^{\mathrm{b}}$ & \\
\hline \multirow{2}{*}{ Heptanal } & Control & $65.32 \pm 11.19^{\mathrm{a}}$ & \multirow{2}{*}{ ns } & $184.72 \pm 27.84^{b}$ & \multirow{2}{*}{ ns } & $978.26 \pm 58.50^{\mathrm{b}}$ & \multirow{2}{*}{$* * *$} \\
\hline & Modified & $114.08 \pm 35.58^{\mathrm{a}}$ & & $187.34 \pm 41.72^{\mathrm{b}}$ & & $197.89 \pm 11.56^{\mathrm{b}}$ & \\
\hline \multirow{2}{*}{$\mathrm{t}$-2-Heptenal } & Control & $30.86 \pm 5.88^{\mathrm{a}}$ & \multirow{2}{*}{$* *$} & $168.79 \pm 22.19^{\mathrm{a}}$ & \multirow{2}{*}{$* * *$} & $1,753.15 \pm 307.33^{b}$ & \multirow{2}{*}{$* *$} \\
\hline & Modified & $<0.01^{\mathrm{a}}$ & & $<0.01^{\mathrm{a}}$ & & $122.04 \pm 18.69^{\mathrm{b}}$ & \\
\hline \multirow{2}{*}{$\begin{array}{l}\text { 2-Pentil } \\
\text { amilofurane }\end{array}$} & Control & $360.14 \pm 34.15^{\mathrm{a}}$ & \multirow{2}{*}{ ns } & $776.60 \pm 303.19^{b}$ & \multirow{2}{*}{ ns } & $4,512.55 \pm 259.05^{\mathrm{c}}$ & \multirow{2}{*}{$* * *$} \\
\hline & Modified & $459.47 \pm 102.70^{\mathrm{a}}$ & & $778.36 \pm 313.11^{\mathrm{a}}$ & & $673.43 \pm 48.66^{\mathrm{a}}$ & \\
\hline \multirow{2}{*}{ Octanal } & Control & $127.35 \pm 3.37^{\mathrm{a}}$ & \multirow[b]{2}{*}{ ns } & $282.87 \pm 67.53^{\mathrm{a}}$ & \multirow[b]{2}{*}{ ns } & $1,376.74 \pm 200.96^{b}$ & \multirow{2}{*}{$* * *$} \\
\hline & Modified & $181.56 \pm 57.17^{\mathrm{a}}$ & & $259.91 \pm 43.01^{\mathrm{a}}$ & & $237.65 \pm 17.46^{\mathrm{a}}$ & \\
\hline \multirow{2}{*}{$\mathrm{t}, \mathrm{t}-2,4$-Heptadienal } & Control & $4.78 \pm 5.53^{\mathrm{a}}$ & \multirow{2}{*}{$* * *$} & $<0.01^{\mathrm{a}}$ & \multirow{2}{*}{ ns } & $238.94 \pm 39.63^{b}$ & \multirow{2}{*}{$* * *$} \\
\hline & Modified & n.d. & & n.d. & & n.d. & \\
\hline \multirow{2}{*}{ 2-Octenal } & Control & $48.04 \pm 6.41^{\mathrm{a}}$ & \multirow{2}{*}{ ns } & $121.28 \pm 31.83^{\mathrm{a}}$ & \multirow{2}{*}{ ns } & $2,061.42 \pm 130.85^{\mathrm{b}}$ & \multirow{2}{*}{$* * *$} \\
\hline & Modified & $54.54 \pm 25.02^{b}$ & & $78.62 \pm 14.96^{\mathrm{b}}$ & & $<0.01^{\mathrm{a}}$ & \\
\hline & Control & $506.41 \pm 122.10^{\mathrm{a}}$ & & $1,218.75 \pm 100.80^{b}$ & * & $3,037.76 \pm 196.58^{\mathrm{c}}$ & \\
\hline Nonanal & Modified & $1,484.74 \pm 91.02^{\mathrm{a}}$ & $* *$ & $2,015.49 \pm 392.51^{\mathrm{a}}$ & & $1,484.33 \pm 286.45^{\mathrm{a}}$ & NRA \\
\hline t t 24 Nonodionol & Control & $12.11 \pm 2.47^{\mathrm{a}}$ & $* *$ & $20.78 \pm 5.76^{\mathrm{a}}$ & ** & $280.79 \pm 58.07^{\mathrm{b}}$ & * \\
\hline l,l-2,4-1 Nonadienal & Modified & n.d. & nes & n.d. & 等 & n.d. & a \\
\hline t t 24 Decodianol & Control & $13.31 \pm 4.77^{\mathrm{a}}$ & & $99.48 \pm 21.79^{\mathrm{a}}$ & & $2,632.31 \pm 452.69^{\mathrm{b}}$ & $* * *$ \\
\hline t,t-2,4-Decadienal & Modified & $<0.01^{\mathrm{a}}$ & * & $35.97 \pm 1.11^{\mathrm{a}, \mathrm{b}}$ & wh & $105.77 \pm 82.37^{\mathrm{b}}$ & war \\
\hline 24 Docodionol & Control & $74.22 \pm 33.62$ & $*$ & $508.75 \pm 94.55^{\mathrm{a}}$ & $* *$ & $11,944.91 \pm 2,424.12^{b}$ & $* *$ \\
\hline 2,4-Decadienal & Modified & n.d. ${ }^{\mathrm{a}}$ & 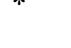 & $168.65 \pm 6.00^{\mathrm{a}, \mathrm{b}}$ & wa & $436.81 \pm 324.35^{\mathrm{b}}$ & r. \\
\hline & Control & $2,612.05 \pm 94.17^{\mathrm{a}}$ & & $5,306.74 \pm 1,390.34^{\mathrm{a}}$ & & $46,732.22 \pm 4,517.29^{b}$ & \\
\hline 2 Volatile & Modified & $3,107.95 \pm 606.37^{\mathrm{a}}$ & ns & $5,000.53 \pm 1,178.09^{\mathrm{a}, \mathrm{b}}$ & ns & $6,979.08 \pm 2,805.43^{b}$ & F*a \\
\hline
\end{tabular}

TBARS are expressed in $\mathrm{mg}$ MDA/kg and the volatile compounds in ng dodecane/g dry matter, both as mean \pm standard deviation. Student't test compares differences between both types of dry fermented sausages. LS (level of significance): ns (not significant); $P>$ $0.05 ; * P<0.05 ; * * P<0.01$; *** $P<0.001$. Different letters in the same row denote significant differences $(P<0.05)$ among the different times according to an ANOVA test and Tuckey $b$ post hoc test. 
but reached $1.4 \mathrm{ppm}$ in Control batches. Zanardi [40] reported mean values of $0.34 \mathrm{ppm}$ in traditional dry fermented sausages after 60 days with a protective atmosphere, considering these values as acceptable in this type of products. In the present work, although under aerobic storage, the Modified batches showed after of 90 days acceptable values of TBARS, pointing out the protective activity of Melissa officinalis on these new formulations. Other vegetal sources of phenolic compounds such as rosemary showed also an effective inhibitor effect of the formation of lipid oxidation products in sucuk, a Turkish dry fermented sausage [41].

Following a similar trend, the volatile compounds related to the oxidation process showed an increase during the storage time for both products, which was more intense in Control products. Hexanal, the typical oxidation marker of linoleic acid, is considered as a good indicator of the oxidation level [42]. Hexanal only showed significant increases for both type of batches during the last 60 days of storage, being this increment much higher than in Modified batches. A similar fact occurred in dry fermented sausages enriched in linseed oil elaborated by Valencia [39], where the hexanal content, after of 2 and 5 months of aerobic storage increased much less than in the traditional formulation. Regarding the total volatile compounds, a similar behavior was observed. Heptanal, octanal and nonanal showed along the time higher increases in the Control batch than in Modified. High hexanal values and other aldehydes with an important increase of TBARS value suggested that at 90th day the Control batch underwent significant oxidation process that could lead to the generation of compounds associated to rancid taste and odors [1]. No peaks of t,t-2,4-Heptadienal, t,t-2,4-Nonadienal, and low peaks of 2-Octenal and 2,4-Decadienal were detected in Modified batches. All these compounds are strongly related with the sensorial aspects, due to their off odour and low threshold [43]. In general, in the Modified products a slower rate formation of volatile lipid oxidation derived compound was detected, suggesting that the lyophilized water extract of Melissa officinalis performed a protective role along the storage time necessary to prolong the shelf life of the product.

\section{Conclusion}

In conclusion, the lyophilized water extract of $M$. officinalis protected $\omega-3$ PUFA and long chain $\omega-3$ PUFA of dry fermented sausages from oxidation along the storage time, guaranteeing the nutritional improvements achieved with the new formulation.

\section{References}

[1] D. Ansorena, I. Astiasarán. Effect of storage and packaging on fatty acid composition and oxidation in dry fermented sausages made with added olive oil and antioxidants, Meat Sci. 67 (2004) 237-244.

[2] D. Ansorena, I. Astiasarán, The use of linseed oil improves nutritional quality of the lipid fraction of dry-fermented sausages, Food Chem. 87 (2004) 69-74.

[3] K. Raes, S. De Smet, D. Demeyer, Effect of dietary fatty acids on incorporation of long chain polyunsaturated fatty acids and conjugated linoleic acid in lamb, beef and pork meat: A review, Anim. Feed Sci. Technol. 113 (2004) 199-221.

[4] L. Haak, K. Raes, K. Smet, E. Claeys, H. Paelinck, S. De Smet, Effect of dietary antioxidant and fatty acid supply on the oxidative stability of fresh and cooked pork, Meat Sci. 74 (2006) 476-486.

[5] I. Valencia, D. Ansorena, I. Astiasarán, Nutritional and sensory properties of dry fermented sausages enriched with n-3 PUFAs, Meat Sci. 72 (2006) 727-733.

[6] I. Valencia, D. Ansorena, I. Astiasarán, Development of dry fermented sausages rich in docosahexaenoic acid with oil from the microalgae Schizochytrium sp.: Influence on nutritional properties, sensorial quality and oxidation stability, Food Chem. 104 (2007) 1087-1096.

[7] E. Cáceres, M.L. García, M.D. Selgas, Effect of pre-emulsified fish oil-as source of PUFA n-3-on microstructure and sensory properties of mortadella, a Spanish bologna-type sausage, Meat Sci. 80 (2008) 183-193.

[8] M. García-Íñiguez de Ciriano, C. García-Herreros, E. Larequi, I. Valencia, D. Ansorena, I. Astiasarán, Use of natural antioxidants from lyophilized water extracts of Borago officinalis in dry fermented sausages enriched in $\omega-3$ PUFA, Meat Sci. 83 (2009) 271-277. 
[9] M. García-Íñiguez de Ciriano, E. Larequi, S. Rehecho, M.I. Calvo, R.Y. Cavero, Í. Navarro-Blasco, et al., Selenium, iodine, $\omega-3$ PUFA and natural antioxidant from Melissa officinalis L.: A combination of components from healthier dry fermented sausages formulation, Meat Sci. 85 (2010) 274-279.

[10] I. Berasategi, S. Legarra, M. García-Íñiguez de Ciriano, S. Rehecho, M.I. Calvo, R.Y. Cavero, et al., "High in omega-3 fatty acids" bologna-type sausages stabilized with an aqueous-ethanol extract of Melissa officinalis, Meat Sci. 88 (2011) 705-711.

[11] WHO, Diet, nutrition and the prevention of chronic diseases, WHO Tech. Rep. Ser. 916 (2003) 0-160.

[12] C.H.S. Ruxton, S.C. Reed, M.J.A. Simpson, K.J. Millington, The health benefits of omega-3 polyunsaturated fatty acids: A review of the evidence, Journal of Human Nutrition and Dietetics 17 (2004) 449-459.

[13] B. Ross, J. Seguin, L. Sieswerda, Omega-3 fatty acids as treatments for mental illness: Which disorder and which fatty acid?, Lipids in Health and Disease 6 (2007) 1-19.

[14] S. Lee, C. Faustman, D. Djordjevic, H. Faraji, E. Decker, Effect of antioxidants on stabilization of meat products fortified with n-3 fatty acids, Meat Sci. 72 (2006) 18-24.

[15] A.P. Simopoulos, N.G. Bazan, World Review of Nutrition and Dietetics, Thomson 2009, 2009.

[16] H. Okuyama, High n-6 to n-3 ratio of dietary fatty acids rather than serum cholesterol as a major risk factor for coronary heart disease, Eur. J. Lipid Sci. Tech. 103 (2001) 418-422.

[17] M.C.W. Myhrstad, R. Kjetil, H.T. Vibeke, O. Inger, H. Bente, B.H. Kirsten,et al., Effect of marine n-3 fatty acids on circulating inflammatory markers in healthy subjects and subjects with cardiovascular risk factors, Inflamm. Res. 60 (2011) 309-319.

[18] R. Bei, A. Frigiola, L. Masuelli, L. Marzocchella, I. Tresoldi, A. Modesti, et al., Effects of omega-3 polyunsaturated fatty acids on cardiac myocyte protection, Frontiers in Bioscience 16 (2011) 1833-1843.

[19] D.V. Byrne, W.L.P. Bredie, L.S. Bak, G. Bertelsen, H. Martens, M. Martens, Sensory and chemical analysis of cooked porcine meat patties in relation to warmed-over flavour and pre-slaughter stress, Meat Sci. 59 (2001) 229-249.

[20] C. Rymer, D.I. Givens, n-3 fatty acid enrichment of edible tissue of poultry: A review, Lipids 40 (2005) 121-130.

[21] P.A. Morrissey, P.J.A. Sheehy, K. Galvin, J.P. Kerry, D.J. Buckley, Lipid stability in meat and meat products, Meat Sci. 49 (1998) S73-S86.

[22] J. Alamed, D.J. McClements, E.A. Decker, Influence of heat processing and calcium ions on the ability of EDTA to inhibit lipid oxidation in oil-in-water emulsions containing omega-3 fatty acids, Food Chem. 95 (2006) 585-590.

[23] J. Gundgaard, J.N. Nielsen, J. Olsen, J. Sorensen, Increased intake of fruit and vegetables: Estimation of impact in terms of life expectancy and healthcare costs, Public Health Nutr. 6 (2003) 25-30.

[24] A. Gosslau, K.Y. Chen, Nutraceuticals, apoptosis, and disease prevention, Nutr. 20 (2004) 95-102.

[25] M. Naczk, F. Shahidi, Phenolics in cereals, fruits and vegetables: Occurrence, extraction and analysis, J. Pharm. Biomed. Anal. 41 (2006) 1523-1542.

[26] S. Khokhar, S.G.M. Magnusdottir, Total phenol, catechin, and caffeine contents of teas commonly consumed in the United Kingdom, J. Agric. Food Chem. 50 (2002) 565-570.

[27] N.V. Yanishlieva, E. Marinova, J. Pokorný, Natural antioxidants from herbs and spices, Europ. J. Lipid Sci. Technol. 108 (2006) 776-793.

[28] M.M. Calvo, M.L. García, M.D. Selgas, Dry fermented sausages enriched with lycopene from tomato peel, Meat Sci. 80 (2008) 167-172.

[29] C. García-Herreros, M. García-Íñiguez de Ciriano, I. Astiasarán, D. Ansorena, Antioxidant activity and phenolic content of water extracts of Borago officinalis L.: Influence of plant part and cooking procedures, Italian J. Food Sci. 22 (2010) 155-164.

[30] M. García-Íñiguez de Ciriano, S. Rehecho, M.I. Calvo, R.Y. Cavero, Í. Navarro-Blasco, I. Astiasarán, et al., Effect of lyophilized water extracts of Melissa officinalis on the stability of algae and linseed oil-in-water emulsion to be used as a functional ingredient in meat products, Meat Sci. 85 (2010) 373-377.

[31] J.L. Lamaison, C. Petitjean-Freytet, J.A. Duke, J. Walker, Hydroxycinnamic derivative levels and antioxidant activity in North American Lamiaceae, Plantes Médicinales et Phytothérapie 26 (1993) 143-148.

[32] V. López, S. Akerreta, E. Casanova, J.M. García-Mina, R.Y. Cavero, M.I. Calvo, In vitro antioxidant and anti-rhizopus activities of Lamiaceae herbal extracts, Plant Foods for Human Nutrition 62 (2007) 151-155.

[33] E. Muguerza, O. Gimeno, D. Ansorena, J.G. Bloukas, I. Astiasaran, Effect of replacing pork backfat with pre-emulsified olive oil on lipid fraction and sensory quality of chorizo de Pamplona-A traditional Spanish fermented sausage, Meat Sci. 59 (2001) 251-258.

[34] J. Folch, M. Lees, G.H.S. Stanley, A simple method for the isolation and purification of total lipids from animal tissues, J. Biol. Chem. 226 (1957) 497-509.

[35] AOAC, Methyl esters of fatty acids in oils and fats, 969.33, in: W. Horwitz (Ed.), Official Methods of Analysis, Association of Official Analytical Chemists, Gaithersburg, Maryland, 2002, pp. 19-20. 


\section{A Lyophilized water extract of Melissa officinalis L. as an effective natural antioxidant during the storage of dry fermented sausages high in $\alpha$-linolenic acid and DHA}

[36] B.G. Tarladgis, B.M. Watts, M.T. Younathan, L. Dugan, A distillation method for the quantitative determination of malonaldehyde in rancid foods, J. Am. Oil Chem. Soc. 37 (1960) 44-48.

[37] B.G. Tarladgis, A.M. Pearson, L.R.Jr. Dugan, Chemistry of 2-thiobarbituric acid test for determination of oxidative rancidity in foods: II. Formation of TBA-malonaldehyde complex without acid-heat treatment, J. Sci. Food Agric. 15 (1964) 602-607.

[38] D. Ansorena, M.J. Zapelena, I. Astiasarán, J. Bello, Addition of palatase M (lipase from Rhizomucor miehei) to dry fermented sausages: Effect over lipolysis and study of the further oxidation process by GC-MS, J. Agric. Food Chem. 46 (1998) 3244-3248.

[39] I. Valencia, D. Ansorena, I. Astiasarán, Stability of linseed oil and antioxidants containing dry fermented sausages: A study of the lipid fraction during different storage conditions, Meat Sci. 73 (2006) 269-277.

[40] E. Zanardi, V. Dorigoni, A. Badiani, R. Chizzolini, Lipid and colour stability of milano-type sausages: Effect of packing conditions, Meat Sci. 61 (2002) 7-14.

[41] V. Gok, E. Obuz, M. Ekin Sahin, A. Serteser, The effects of some natural antioxidants on the color, chemical and microbiological properties of sucuk (Turkish dry-fermented sausage) during ripening and storage periods, J. Food Process. Preserv. 35 (2011) 677-690.

[42] F. Shahidi, R.B. Pegg, Hexanal as an indicator of the flavor deterioration of meat and meat products, ACS Symp. Ser. (1994) 256-279.

[43] E.N. Frankel, Lipid oxidation, the oily press LTD, 6 Dunnottar Place, West Ferry, Dundee, Scotland DD5 1PJ, 1998. 